\title{
ALLIUM (AMARYLLIDACEAE) SPECIES IN PAKISTAN: TWO NEW RECORDS AND A NEW SPECIES FROM ZHOB (BALOCHISTAN)
}

\author{
NAZAR KHAN ${ }^{*}$, REINHARD M. FRITSCH ${ }^{2}$, AMIR SULTAN ${ }^{3}$ AND TAHIR KHAN ${ }^{4}$ \\ ${ }^{1}$ Department of Botany, Government Degree College, Zhob, Balochistan, Pakistan \\ ${ }^{2}$ Leibniz Institute of Plant Genetics and Crop Plant Research, Gatersleben, Germany \\ ${ }^{3}$ National Herbarium, National Agricultural Research Centre, Islamabad, Pakistan \\ ${ }^{4}$ Army Public School and College, Zhob, Balochistan, Pakistan \\ *Corresponding author's email: nazar822@yahoo.com
}

\begin{abstract}
Allium caroli-henrici, A. registanicum are newly recorded from Zhob district of Pakistan, and a new species Allium zhobicum is described and illustrated. The new species belongs to Allium subg. Melanocrommyum sect. Thaumasioprason and is characterized by rounded bulbs with coriaceous outer tunics, entire to papillate linear leaves, lilac to white scarcely recurved, elliptical linear to oblong tepals and a six-lobed ovary with exserted stigma and violet style. The key to Allium species in Flora of Pakistan is amended including the diagnostic characters of the newly recorded species.
\end{abstract}

Key words: Allium zhobicum, Allium caroli-henrici, Allium registanicum, taxonomy, description, distribution, SW Asia

\section{Introduction}

Allium $\mathrm{L}$ is a genus with currently more than 980 accepted species making it one of the largest monocotyledonous genera of the world (Govaerts et al., 2020) mainly distributed throughout the northern hemisphere (Hanelt, 1990; Fritsch \& Friesen, 2002; Friesen et al., 2006). Worldwide about 50 species are important as widely or locally cultivated plants. Moreover, many wild alliums are collected by the local population for human consumption as spices, vegetables and medical plants, and also as ornamentals. Several wild species own a great potential as valuable part of the daily human diet, and as part of the fodder for livestock (Fritsch \& Abbasi, 2013). Molecular marker analyses support to classify Allium into 15 subgenera and about 80 sections (Friesen et al., 2006; Fritsch et al., 2010). The genus Allium was formerly included in the Liliaceae family or as separate family Alliaceae, but the Angiosperm Phylogeny Group (APG) reassessed the taxonomic position of this genus and related genera that are currently placed in the Amaryllidaceae family (Anon., 2009).

During field studies in the district Zhob (northern Balochistan) some Allium species were collected. Two of them were identified as A. caroli-henrici Wendelbo and $A$. registanicum Wendelbo earlier not recorded for Pakistan, and one species could not be identified when compared with the species described in the Flora of Pakistan (Nasir, 1975) and Flora Iranica (Wendelbo, 1971). This species is newly described and illustrated here. In Pakistan, 41 Allium species were formerly recorded (Nasir, 1975), and with the addition of these 3 species, this genus is represented by 44 species now.

\section{Results}

Allium zhobicum Nazar Khan, Amir Sultan \& R.M. Fritsch, species nova.

Figs. 1-6, 17

Type: Balochistan, Zhob district, Qamardin Karez, Khutkandai, 3131'31'N 68¹4'38'E, Nazar Khan Mandokhel, 24 April, 2020 (RAW101342).
Diagnosis: The shape of ovary is most similar to $A$. mirum Wendelbo, but this species has papery outer bulb tunics and up to $8 \mathrm{~cm}$ broad, elliptical leaves, a campanulate perigonium, up to $3 \mathrm{~cm}$ long pedicels, and longer obovate tepals of brown purple colour. The violet upper parts of filaments are similar to those of $A$. hindukuschense Kamelin \& Seisums, but A. zhobicum differs from A. hindukuschense by much broader and scarcely recurved tepals of lilac colour and with rounded apices, and spherical ovaries.

Description: Bulbs 1.5-2.5 cm in diameter, globose; outer tunics initially light brown, delicate and fragile but coriaceous and brown when dry; inner tunics membranous, white. Scape 10-30 cm long, cylindrical, glabrous, green to yellowish green. Leaves 1-3, longer than scape, linear, 5-10 (18) $\mathrm{mm}$ broad, margins entire towards apex and papillate towards base. Spathe membranous, up to $1 \mathrm{~cm}$ with brownish nerves, splitting into 3 lobes longitudinally to obliquely. Umbel hemispherical, dense. Pedicels unequal, 10-20 mm long, green to purple. Perigonium stellate, tepals whitish lilac to lilac with violet to purple nerve, $6-7 \mathrm{~mm}$ long and 1.5-1.8 $\mathrm{mm}$ broad, elliptical-linear to oblong, recurved, obtuse to acute, outer tepals broader at base than inner ones. Filaments narrow triangular, at base connate and adnate to tepals, shorter to slightly longer than tepals, violet at apex becoming creamy toward base; inner filaments slightly broader at base than outer ones. Anthers 1-2 $\mathrm{mm}$, violet to brownish, dorsifixed. Ovary green, six lobed depressed-globose; style 3-6 mm, filiform, exserted; stigma violet. Capsule triangular, greenish white, olive green at angle; seeds black, 2-3 mm long, irregularly shaped to ovate and D-shaped.

Plants growing on sandy clay to sandy loamy soil near Chukhan have longer scapes, larger leaves, and lax flowers with pinkish-lilac tepals.

Vernacular name: Khatol.

Etymology: The species is named after the Zhob district. 
Distribution: Found in several localities in Zhob district (Chukhan, Larai, Khutkandai, Qamardin Karez) along the border to Afghanistan.

Ecology: Usually found growing in sandy loam.

Ethnobotany: The whole plant is edible. Especially the bulbs are collected in large amounts by the local population and are eaten raw. The species might become threatened by over-collecting in the future. The flowers are also eaten by goats and sheep.

Additional specimens examined: Balochistan, Zhob district, Chukan, $31^{\circ} 15^{\prime} 39^{\prime} \mathrm{N}$ 68 $8^{\circ} 52^{\prime} 40^{\prime \prime} \mathrm{E}, 2017 \mathrm{~m}$ asl, Nazar Khan Mandokhel, 23 April, 2020 (RAW 101348).

The new species belongs to $A$. subg. Melanocrommyum (Webb \& Berthel.) Rouy sect. Thaumasioprason Wendelbo.

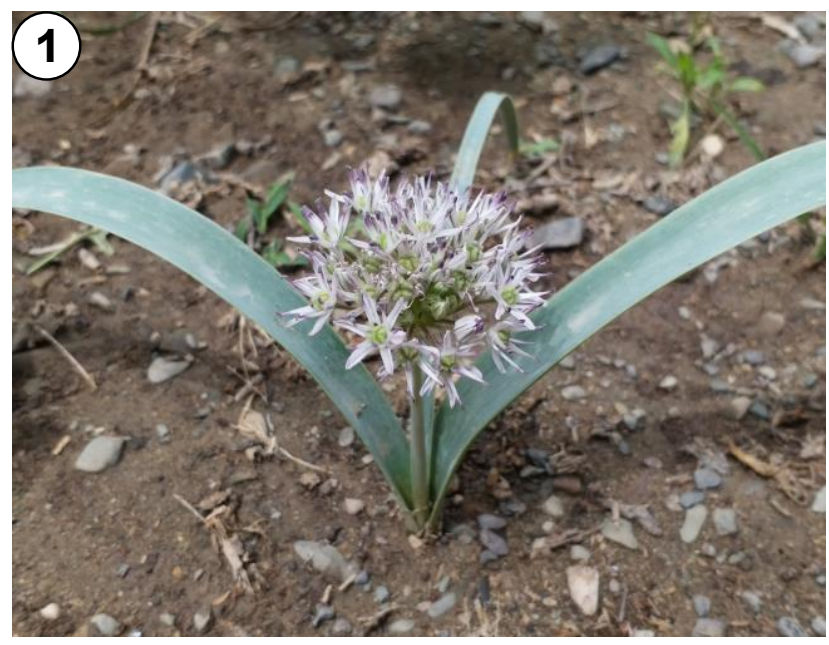

Fig. 1. Allium zhobicum, plant habit. Photo by Nazar Khan.
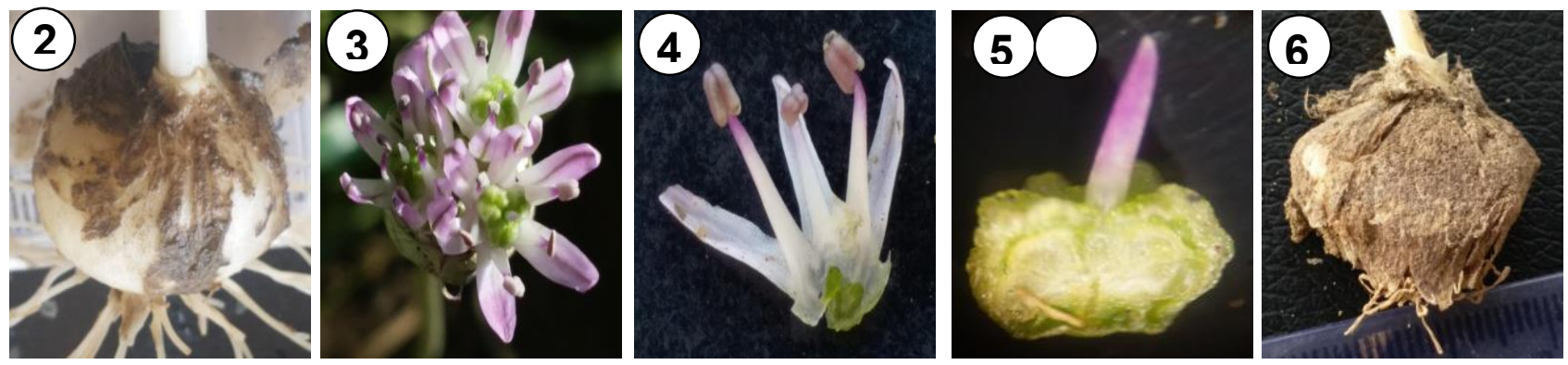

Figs. 1-6. Allium zhobicum. Fig. 2: Fresh bulb tunics. Fig. 3. Small umbel with lilac tepals. Fig. 4. Flower section with tepals and stamens. Fig. 5. Ovary with style and stigma. Fig. 6. Dry bulb tunics. Photos by Nazar Khan.

Allium caroli-henrici Wendelbo (Bot. Not. 121: 274, 1968) Figs. 7-11, 17

Bulbs $3 \mathrm{~cm}$ long, 1.5-2.2 cm in diameter, globose, with coriaceous, blackish to dark brown, longitudinally split outer tunics; inner tunics thin, pale to light brown. Scape purplish, 8-12 cm erect to slightly flexuose, (subterranean scape 4-4.5 $\mathrm{cm})$. Leaves 1-3, opposite, as long as scape or longer, 3.5-9 $\mathrm{mm}$ wide, linear, margin minutely scabrid. Spathe $0.5-1.5 \mathrm{~cm}$ long, four-lobed, membranous with purple nerves. Umbel hemispherical, dense; with unequal, $1.5-3 \mathrm{~cm}$ long, cylindrical, thin pedicels. Perigonum campanulate; tepals mauve with dark to brownish flush paler at base (purple at tip and yellowish at base when dry), nerve purplish, unequal 7$10 \mathrm{~mm}$ long, obtuse, margins entire, outer tepals elliptic, inner tepals ovate. Filaments nearly half the length of tepals (inner filament slightly longer), 3.5-5.5 mm long, inner filaments subulate broader at base, outer filaments suboblong, filaments connate at base and adnate to tepals. Anthers $2 \mathrm{~mm}$, oblong, dorsifixed, yellow. Ovary ovoid to cylindrical, angular, green, style 2- $3 \mathrm{~mm}$, stigma lobed, mature capsule brownish, triangular obcordate. Seeds black, irregularly shaped, rough, up to $2.5 \mathrm{~mm}$.

\section{Vernacular name: Sur Khatol}

Distribution: Previously only reported as endemic from SW and C. Afghanistan in the provinces Farah, Daykundi and Urozgan (Wendelbo, 1971; Breckle et al., 2013). Newly found in Pakistan in Qamardin Karez west of Zhob district along the border with Afghanistan. A very rare species in our area.

Ecology: Found in red clay loam soils.
Ethnobotany: The bulb is edible.

Specimens examined: Balochistan, Zhob district, Qamardin Karez, Tahir Khan, 16 May, 2019 (RAW100808).

This species also belongs to $A$. subg. Melanocrommyum sect. Thaumasioprason.

Allium registanicum Wendelbo (Bot. Not. 122: 34, 1969). Figs. 12-16, 17

Bulb ovoid $2 \mathrm{~cm}$ long, $1 \mathrm{~cm}$ in diameter, outer tunics brownish, coarsely reticulate, inner tunics white to pale brown, membranous. Scape 1-2, $12-30 \mathrm{~cm}$ long, underground parts covered by leaf sheaths. Leaves 2-5, shorter to longer than the scape, narrow, semi-cylindrical, sub-opposite to sub-verticillate, $0.7-2.2 \mathrm{~mm}$ broad, not fistular. Spathe soft membranous with brownish to purple nerves, 7-10 mm long, upper part almost split. Umbel hemispherical, dense; pedicels unequal, 5-20 mm long. Perigonium campanulate; tepals white to lilac, pale violet flushed, with purple to violet nerve, elliptic to ellipticoblong, 4-5.5 mm long, outer tepals slightly shorter than inner tepals and obtuse, inner tepals obtuse to subobtuse. Filaments shorter to slightly longer than tepals, 4-6 mm long, lilac to purple, connate at base and adnate to tepals, outer filaments triangular, narrower at base than inner filaments, facing the angles of ovary, inner filaments subulate facing the grooves of ovary. Anthers 0.8-1.2 mm long, violet. Style 2-7 mm long, stigma slightly capitate. Capsule depressed globose, triangular, 3-4 × $5 \mathrm{~mm}$ with persistent dry tepals. Seeds black, thin, irregularly ovate, $2-2.5 \mathrm{~mm}$. 


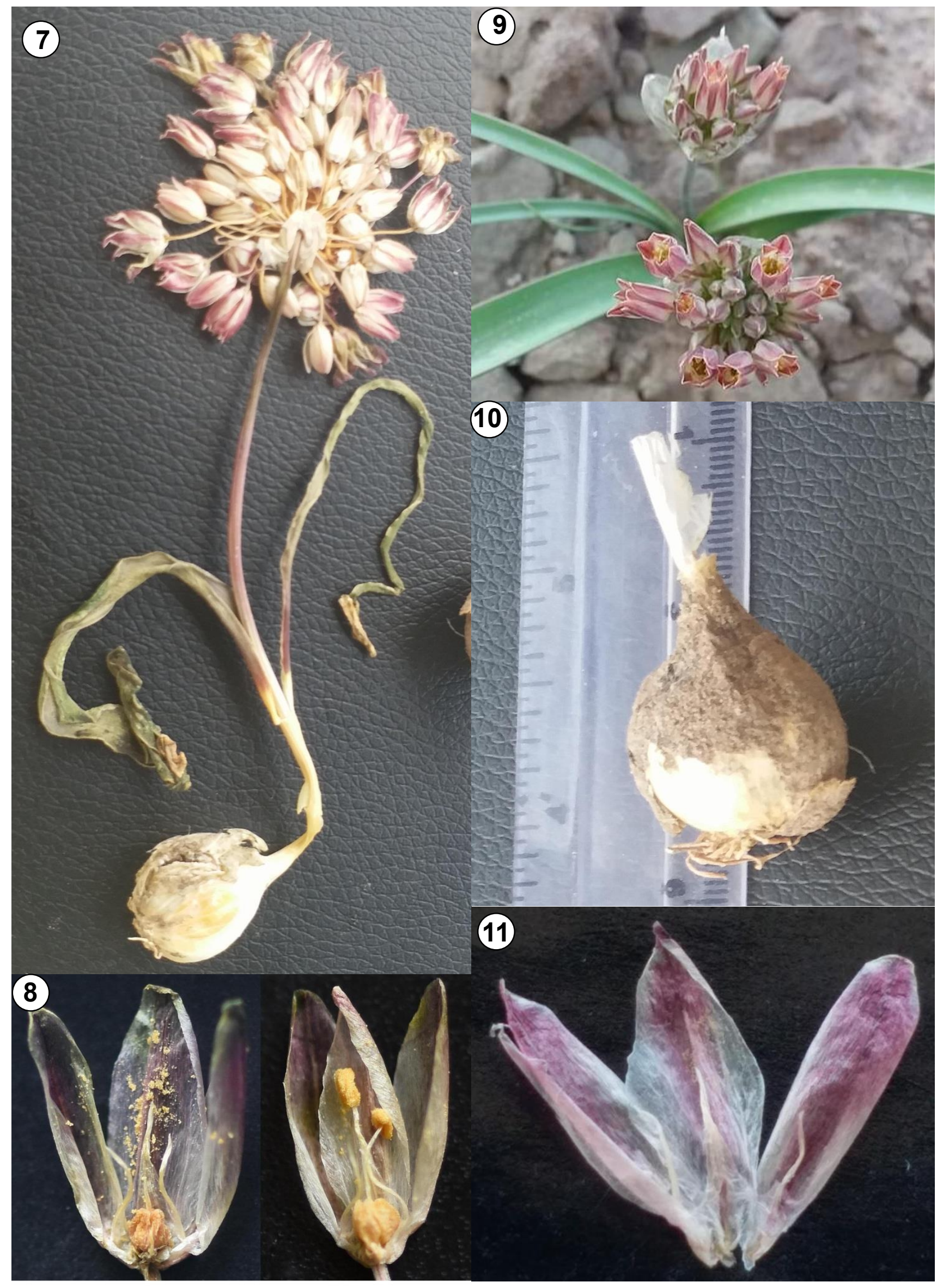

Figs. 7-11. Allium caroli-henrici Fig. 7: Specimen (Tariq Khan, RAW 100808), Fig. 8: Flower sections showing tepals, pistil and stamens, Fig. 9: Habit (Photo by Tahir Khan), Fig. 10.: Bulb, Fig. 11: Flower section showing tepals and filaments. 

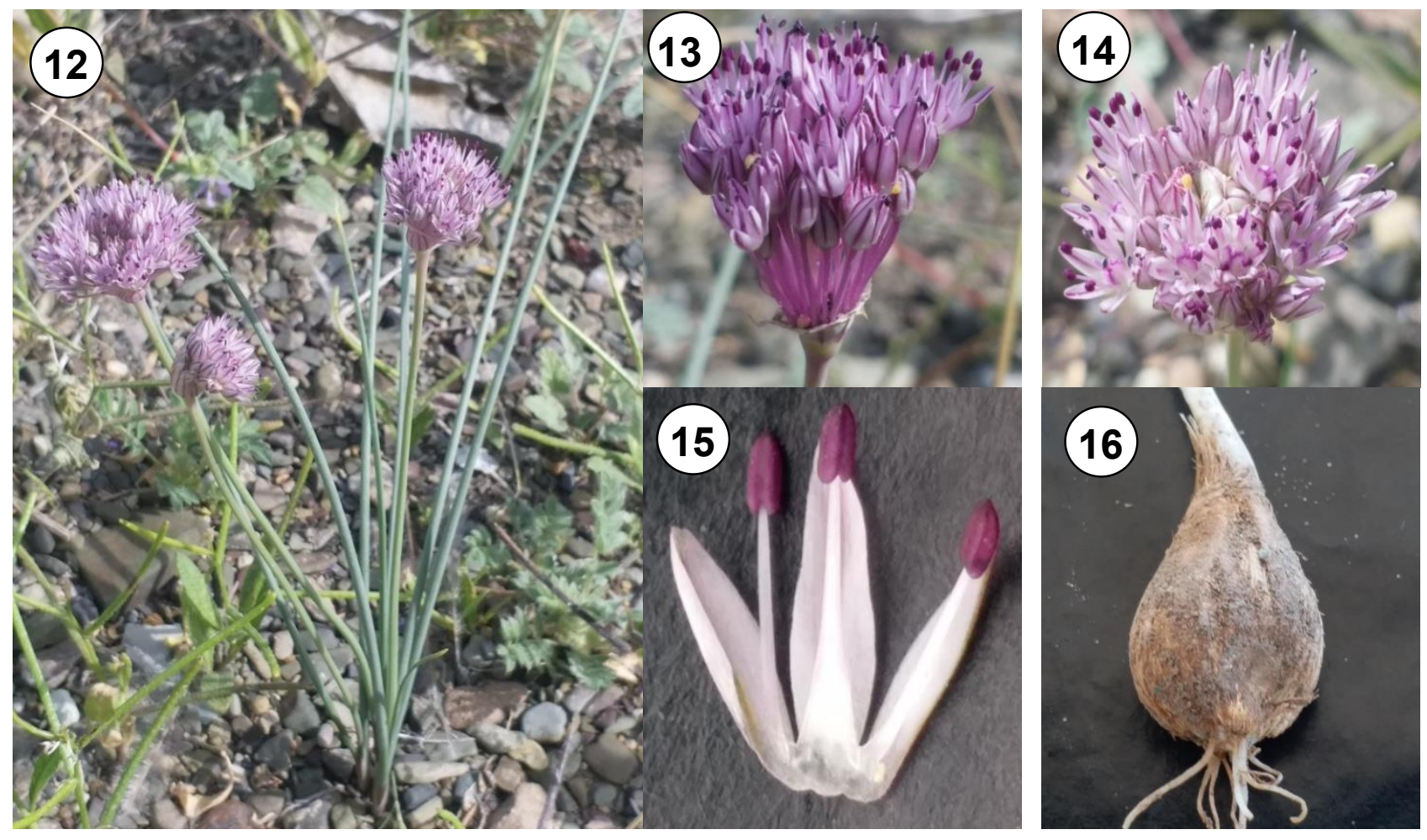

Figs. 12-16. Allium registanicum. Fig. 12. Plant habit, Fig. 13. Inflorescence in early anthesis, Fig. 14. Inflorescence in late anthesis, Fig. 15. Flower section showing filaments and tepals, Fig. 16. Bulb with reticulate tunics. Photos by Nazar Khan.

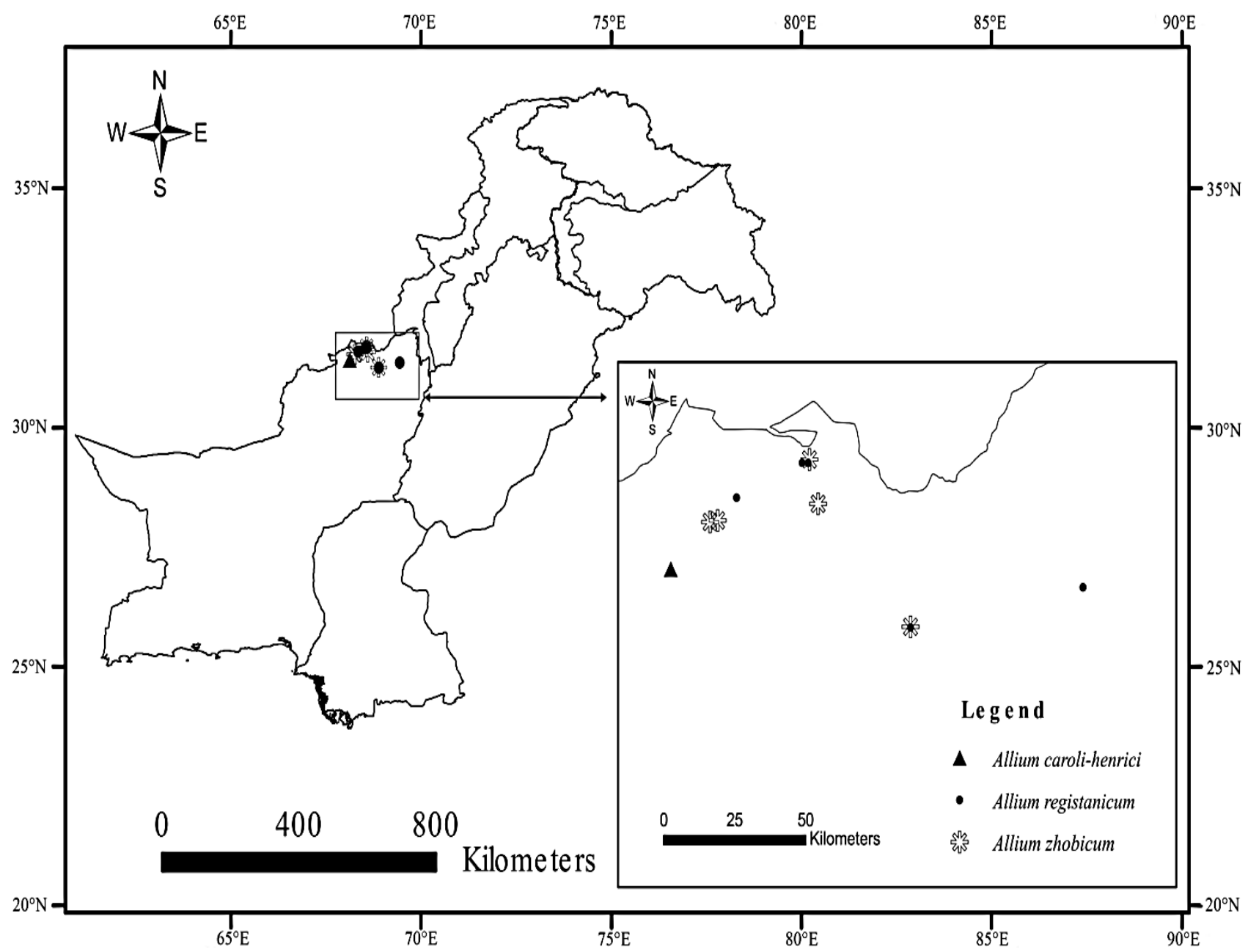

Fig. 17. Distribution of Allium caroli-henrici, A. registanicum and A. zhobicum. 
Vernacular names: Piazian, Anjorai

Distribution: Previously only reported as endemic from S. Afghanistan in the province Qandahar (Wendelbo, 1971; Breckle et al., 2013). Newly found in Pakistan near the village Appozai, Qamardin Karez, Chukhan and Shaghala in the Zhob district.

Ecology: Usually found in sandy to sandy gravel soil in the plains

Ethnobotany: The whole plant is edible, especially the leaves are collected and eaten as salad.
Specimens examined: Balochistan, Zhob district, Appozai village, $31^{\circ} 21^{\prime} 37^{\prime} \mathrm{N}$ 69'25'22'E, Nazar Khan Mandokhel, 25 April, 2019 (RAW100739).

This species belongs to A. subg. Allium sect. Brevispatha Valsecchi.

\section{Amended key to Allium species of Pakistan (based on Nasir, 1975)}

We propose to include the three newly recorded species and their diagnostic characters into the Allium key of "Flora of Pakistan, Alliaceae, No. 83" (Nasir, 1975; nomenclature not modernized and errors in taxonomy not corrected) as follows:

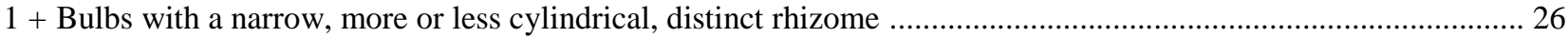

- Bulbs broadly ovoid to subglobose, without a distinct rhizome .................................................................. 2

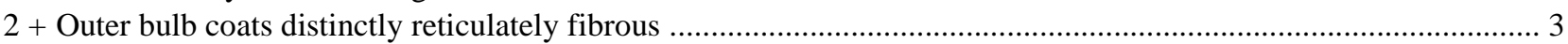

- Outer bulb coats scaly, papery or coriaceous, white to pinkish or grey to brownish ................................... 7

$3+$ Scape 4-10 cm long. Leaves circinate or flexuous Allium stocksianum

- Scape more than $10 \mathrm{~cm}$ long. Leaves neither circinate nor flexuous ....................................................... 4

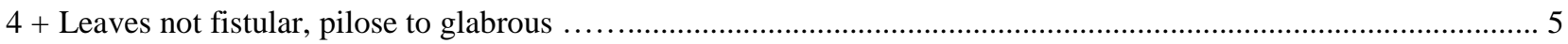

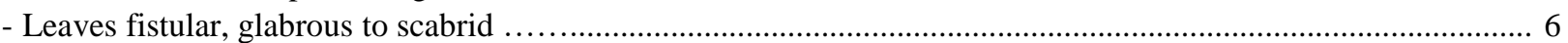

$5+$ Leaves pilose, tepals white, filaments $2 / 3$ of tepal length.

Allium longicollum

- Leaves glabrous, tepals lilac, filaments longer to as long as tepals

Allium registanicum

$6+$ Leaves 3-8, filiform to linear, 1-2 mm broad, up to as long as the plants. Tepals white to rose coloured, veins rosepurple

Allium borszczowii

- Leaves 2-3, filiform, semicylindric, shorter than the plants. Tepals white with greenish veins ........ Allium filidens

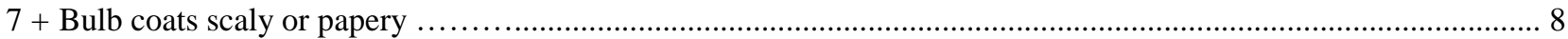

- Bulb outer coats coriaceous, striate or with parallel to reticulate veins . .................................................... 16

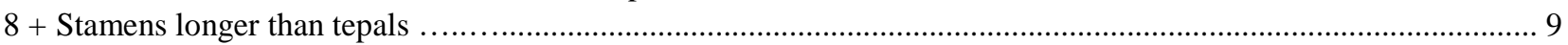

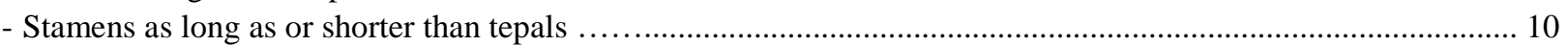

$9+$ Bulb c. $1 \mathrm{~cm}$ broad. Leaves 2, 1.5-3 mm broad. Inner filaments (3-) 5-cuspidate ..................Allium micranthum

- Bulb 3-4 cm broad. Leaves 6-12, 1-2 cm broad. Inner filaments 3-cuspidate ...................... Allium porrum

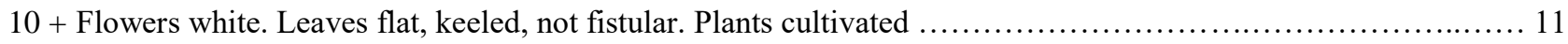

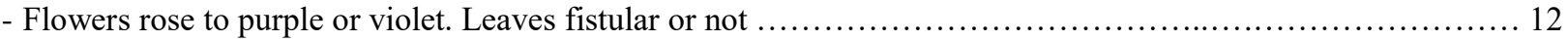

$11+$ Bulbs with 6-10 large scaly bulbils. Inner filaments toothed ................................ Allium sativum

- Bulbs round without scaly bulbils. Filaments entire ..................................... Allium neapolitanum

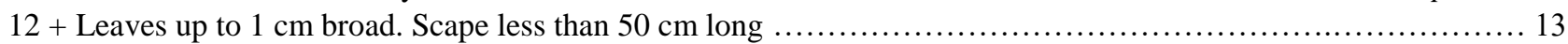

- Leaves 1-5 cm broad. Scape c. $1 \mathrm{~m}$ long ................................................................. 14

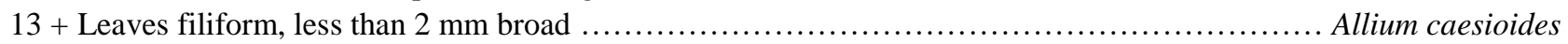

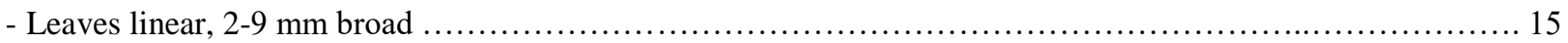

$14+$ Tepals 8-11 mm long, ovate. Filaments triangular, about half the length of the tepals ........... Allium oreophilum

- Tepals 4-6 mm long, lanceolate. Filaments about 3/4 the length of the tepals .................... Allium chitralicum

$15+$ Leaves glabrous ................................................................. Allium rosenbachianum

- Leaves, especially below in the lower part, pilose ......................................... Allium stipitatum

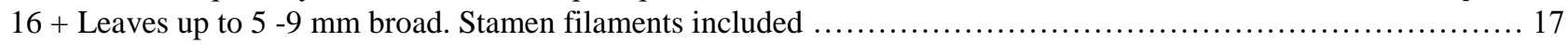

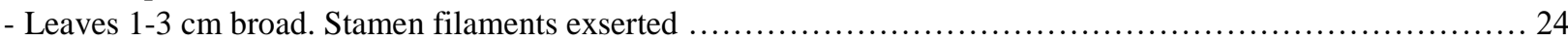

17 + Pedicels 3-4 cm long. Umbels few-flowered. Inner filaments more or less distinctly 2-toothed; teeth short,

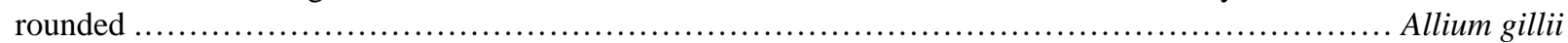

- Pedicels 0.5-30 mm long. Umbels many-flowered, filaments entire ...................................... 18

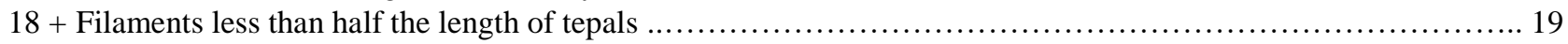

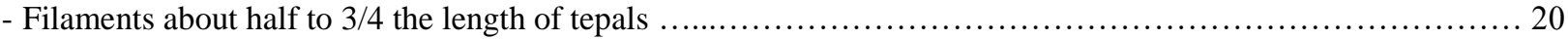

$19+$ About $2 / 3$ of the filaments united, upper parts free. Inner tepals gibbous at the base. Umbel without bulbils Allium griffithianum

- About $1 / 4$ of the filaments united at the base, upper 3/4 of the filaments free. Inner tepals not gibbous at the base. Umbel usually with bulbils Allium umbilicatum

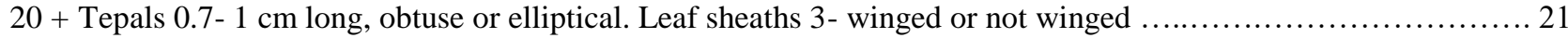

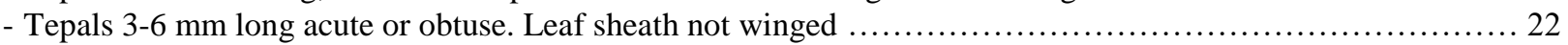


$21+$ Tepals about $1 \mathrm{~cm}$ long, pink to white, filaments $3 / 4$ of tepal length. Leaf sheaths 3 - winged ....... Allium tripterum Tepals about $0.7-1 \mathrm{~cm}$ long, mauve. Filaments half of tepal length. Leaf sheath unwinged....

$22+$ Tepals 5-6 mm long, white, veins reddish, acute. Inner filaments broadly ovate Allium caroli-henrici

- Tepals 3-5 mm long, white or rose, acute or obtuse. Inner filaments triangular Allium lamondiae

23 + Tepals pink coloured, acute. Leaf sheaths glabrous 23

- Tepals white to pinkish, obtuse. Leaf sheaths pubescent

Allium jacquemontii

24 + Scape c. $1 \mathrm{~m}$ long. Pedicels up to $3 \mathrm{~cm}$ long. Tepals 5-6 $\mathrm{mm}$ long Allium miserabile

- Scape 10-30 cm long. Pedicels 1-9 cm long, very unequal. Tepals 6-8 mm long Allium macleanii

$25+$ Scape 10-20 cm, pedicels 1-9 $\mathrm{cm}$, tepals 7-8 $\mathrm{mm}$, oval, obtuse Allium caspium

- Scape 10-30 cm, pedicels 1-2 cm, tepals 6-7 mm, elliptical-linear, recurved, obtuse Allium zhobicum

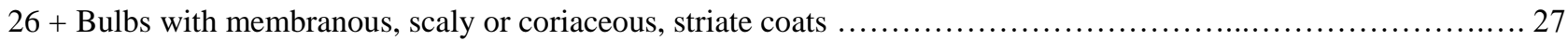

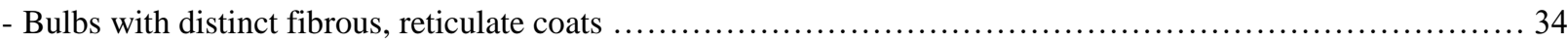

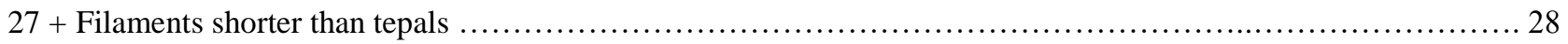

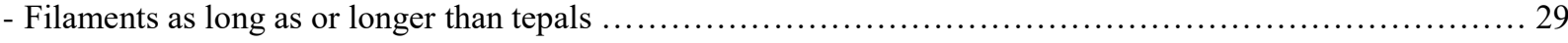

$28+$ Tepals pink. All filaments entire, connate for $1 / 3$ to $1 / 4$ of their length ................... Allium schoenoprasum - Tepals yellow. Inner filaments slightly obtusely toothed, connate for more than half of their lengths

Allium fedschenkoanum

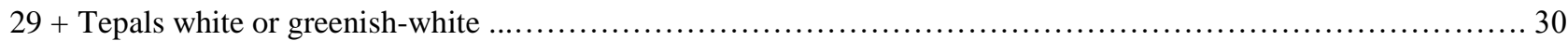

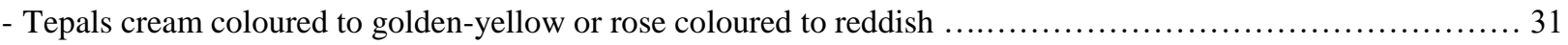

$30+$ Scape fistular, inflated in the middle. Tepals greenish-white. Cultivated ........................... Allium cepa

- Scape neither fistular nor inflated. Tepals white ....................................... Allium farctum

$31+$ Bulb coats membranous, reddish-brown. Inner filaments 2-toothed at the base ........................ Allium roylei

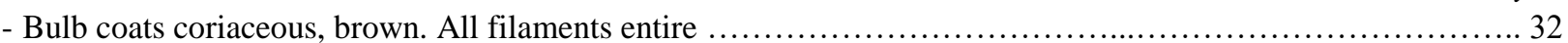

$32+$ Leaves filiform, up to $1 \mathrm{~mm}$ broad, apex acute ............................................ Allium filifolium

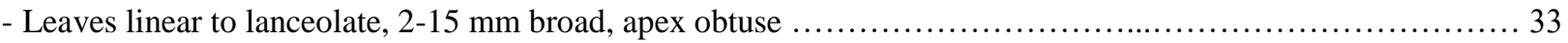

33 + Tepals yellow, sometimes pink. Leaves 3-5, linear, 2-3 mm broad ...................... Allium consanguineum

- Tepals rose coloured. Leaves 5-6, broadly linear, falcate, 5-15 mm broad ................... Allium carolinianum

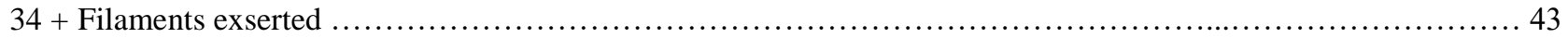

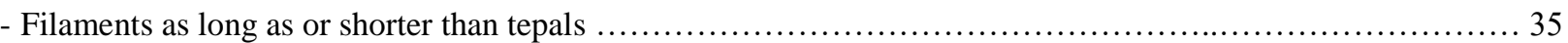

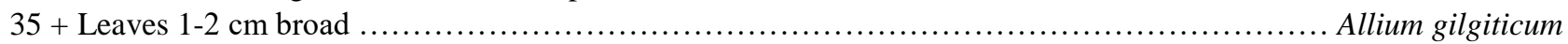

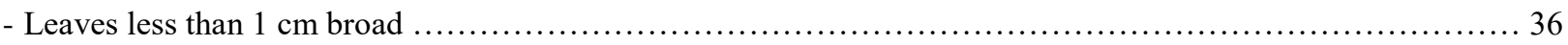

$36+$ Filaments as long as tepals. Style exserted ......................................... Allium dolichostylum

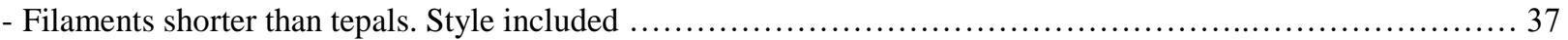

37 + Tepals white, 4-5 mm long, oblong. Inner filaments broad, each with an unilateral tooth ..................................................................... Allium baluchistanicum

- Tepals white to pink or purple to dark purple, oblong, elliptic to ovate or lanceolate, 5 or more $\mathrm{mm}$ long.

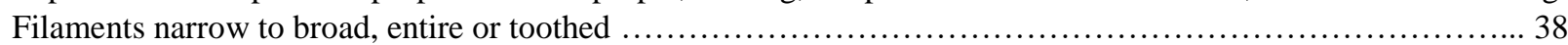

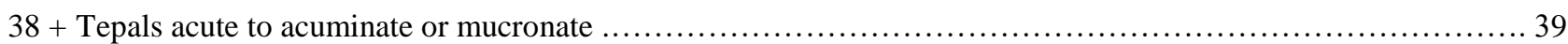

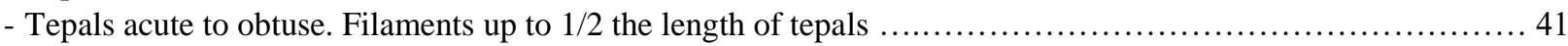

39 + Tepals white, rarely pink, 6-10 mm long, elliptic. Filaments c. 1/2 the length of tepals. Inner filaments narrowly

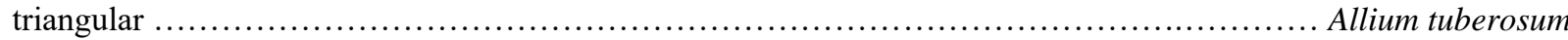

- Tepals pink 5-8 mm long, oblong to lanceolate. Filaments $1 / 2$ to $2 / 3$ the length of tepals. Inner filaments broadly

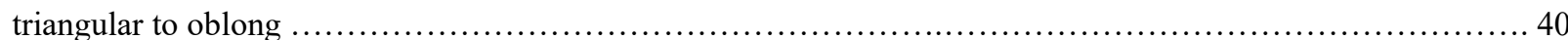

$40+$ Tepals c. $8 \mathrm{~mm}$ long, acuminate. Inner filaments broadly triangular ........................ Allium barsczewskii Tepals 5-6 mm long, apex with a recurved mucro. Inner filaments broadly flattened to oblong ......................................................................... Allium oreoprasum

$41+$ Tepals white, 7-10 mm long, obtuse. Filaments linear to narrowly triangular ...................... Allium humile

- Tepals dark purple, $6-7 \mathrm{~mm}$ long, obtuse to acute. Filaments triangular .................................. 42

$42+$ Filaments c. half the length of tepals; anthers mucronate. Leaves filiform, convolute,

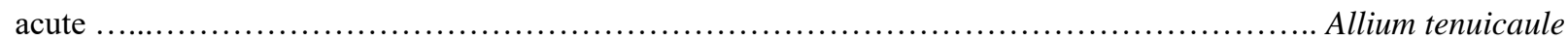

- Filaments less than half the length of tepals; anthers not mucronate. Leaves cylindrical, fistular, 1-3 mm broad,

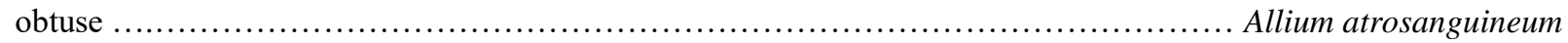

$43+$ Bulb reddish. Tepals pink to purple, c. $6 \mathrm{~mm}$ long, oblong to lanceolate. Leaves linear, c. $1 \mathrm{~mm}$ broad ...................................................................... Allium stoliczkii Bulb brownish. Tepals white to yellowish-white, c. $5 \mathrm{~mm}$ long, oblong. Leaves broadly lanceolate to oval 


\section{Acknowledgements}

We are thankful to Dr. Sayed Afzal Shah for help with drawing the distribution map. Authors are indebted to Mr. Faraz Ahmed and Mr. Saleem for help in photographing the Allium caroli-henrici flower sections.

\section{References}

Anonymous. 2009. Angiosperm Phylogeny Group. An update of the angiosperm phylogeny group classification for the orders and families of flowering plants: APG III. Bot. J. Linn. Soc., 161: 105-121. doi: 10.1111/j.1095-8339.2009.00996.

Breckle, S.W., I.C. Hedge and M.D. Rafiqpoor. 2013. Vascular Plants of Afghanistan - an Augmented Checklist. Scientia Bonnensis, Germany. 597 pp.

Friesen, N., R.M. Fritsch and F.R. Blattner. 2006. Phylogeny and new intrageneric classification of Allium (Alliaceae) based on nuclear ribosomal DNA ITS sequences. Aliso, 22: 372-395.

Fritsch, R.M. and M. Abbasi. 2013. A Taxonomic Review of Allium subg. Melanocrommyum in Iran. Leibniz Institut für
Pflanzengenetik und Kulturpflanzenforschung, Germany. 240 pp., http://www.ipk-gatersleben.de/gbisipkgaterslebendegbis-i/spezialsammlungen/allium-review/

Fritsch, R.M. and N. Friesen. 2002. Evolution, domestication and taxonomy. In: H.D. Rabinowitch and L. Currah (Eds.), Allium crop science: recent advances. CABI publishing, Wallingford, pp. 5-30. doi: 10.1079/9780851995106.0005.

Fritsch, R.M., F.R. Blattner and M. Gurushidze. 2010. New classification of Allium L. subg. Melanocrommyum (Webb \& Berthel.) Rouy (Alliaceae) based on molecular and morphological characters. Phyton (Horn, Austria), 49: 145220.

Govaerts, R., N. Friesen, R. Fritsch and S. Brullo. 2020. World checklist of Amaryllidaceae - Allium. Facilitated by the Royal Botanic Gardens, Kew. Published on the Internet; http://wcsp.science.kew.org/ Retrieved 25 May, 2020.

Hanelt, P. 1990. Taxonomy, evolution, and history. In: (Eds.): Rabinowitch, H.D. and J.L. Brewster. Onions and allied crops (Volume 1). CRC Press, Boca Raton, pp. 1-26.

Nasir, E. 1975. Alliaceae. In: (Eds.): Nasir, E. and S.I. Ali, Flora of Pakistan. No. 83. Karachi, Pakistan.

Wendelbo, P. 1971. Alliaceae. In: (Ed.): Rechinger, K.H. Flora Iranica. No. 76. Graz, Austria.

(Received for publication 11 October 2019) 